\title{
INCRÍVEL: OS IDEAIS SÃO OS MESMOS - OUTRA VEZ!
}

\author{
INCREDIBLE: THE IDEALS ARE THE SAME - AGAIN!
}

\section{TCBC Roberto Saad Junior, Presidente do CBC}

O bem maior conseguido neste País foi a conquista do estado democrático de direito. Esta situação permite que qualquer cidadão tenha suas idéias e, no momento em que se sentir prejudicado por ação que julgar deletéria, pode e tem o dever de reclamar à justiça a injustiça cometida.

O Colégio Brasileiro de Cirurgiões tem um Diretório Nacional, fruto de um processo eleitoral. Um processo democrático. Por isto mesmo aceita elogios e críticas de todos os tipos. Os elogios não precisam ser comentados, pois atender os ideais dos nossos Membros é nossa obrigação. Por outro lado, as críticas, embora sadias, devem ser comentadas. Vamos a elas.

No Editorial da nossa Revista (vol. 31- $\mathrm{n}^{\mathrm{o}} 1$, $\mathrm{jan} / \mathrm{fev}$ 2004) escreveu-se sobre um tema de extrema importância para o Colégio Brasileiro de Cirurgiões: MESMOS"

"INCRÍVEL: OS IDEAIS SÃO OS

O objetivo deste artigo foi mostrar que os Deputados da Frente Parlamentar da Saúde, liderados pelo Dr. Rafael Guerra, apresentam os mesmos anseios que preocupam não somente o C.B.C., mas também todas as outras Sociedades Médicas. E mais, que o C.B.C, através do nobre Deputado, havia finalmente encontrado uma porta aberta, para que pudéssemos expor nossos pensamentos perante os Deputados Federais, lá em Brasília. Neste momento, gostaria de fazer uma pequena pausa e perguntar: os senhores não acham isto importante?

Voltemos ao assunto. Pois bem, a Presidência deste Diretório Nacional tem recebido várias mensagens, em consequiência do que foi dito acima: algumas duvidando, outras não acreditando e, mais ainda, que somos omissos!

No dia 17 de abril do corrente ano, o Deputado Rafael Guerra esteve presente no anfiteatro do C.B.C, a convite do Diretório Nacional, e durante três horas discutiu os assuntos pertinentes à Saúde, ao lado dos representantes de todas as especialidades cirúrgicas. Quis de imediato formar grupos de trabalho, mostrando um entusiasmo jovial inquietante.

E mais, convidou o $\mathrm{CBC}$ a ter assento na Câmara dos Deputados, na sala de Comissão de Seguridade Social e Família ( anexo II, plenário 7), no dia 04 de maio, para discutir a seguinte pauta:

1. Reajuste da Tabela SUS

2. Regulamentação da Emenda 29

3. Financiamento dos Hospitais Universitários

4. Saúde Suplementar

5. Classificação Brasileira Hierarquizada de Procedimentos Médicos.

O C.B.C. esteve presente e testemunhou a luta destes parlamentares, que é, repito, também a nossa. Continuaremos freqüentando estas reuniões. Tenho certeza de que nossas opiniões serão ouvidas; apoiaremos com responsabilidade e defenderemos com firmeza as idéias aí emanadas, com o intuito de convencer o Governo Federal de que, na área da Saúde, muito temos que mudar.

Obrigado Deputado Rafael Guerra, por esta oportunidade.

Membros do C.B.C., enviem propostas, criticas. Não se acomodem, estamos aguardando. 